\title{
Assessment of the relationship between socio-demographic factors and intensity of perceived stress in a group of women hospitalized due to miscarriage
}

\author{
Ocena zależności pomiędzy czynnikami socjodemograficznymi
} a natężeniem odczuwanego stresu w grupie kobiet hospitalizowanych z powodu poronienia

\author{
Mariola Kicia ${ }^{1, A, C-D \oplus}$, Agnieszka Skurzak ${ }^{1, B \oplus}{ }^{\oplus}$, Magdalena Korżyńska-Piętas $^{1, B \oplus}{ }^{\oplus}$ Agnieszka Palus ${ }^{2, B \oplus}$, \\ Grażyna Jolanta Iwanowicz-Palus ${ }^{1, E-F} \oplus$ \\ ${ }^{1}$ Chair and Department of Development in Midwifery, Faculty of Health Sciences, Medical University, Lublin, Poland \\ ${ }^{2}$ Faculty of Medicine, Medical University, Warsaw, Poland \\ A - Research concept and design, B - Collection and/or assembly of data, C - Data analysis and interpretation, \\ $D$ - Writing the article, E - Critical revision of the article, F - Final approval of article \\ Kicia M, Skurzak A, Korżyńska-Piętas M, Palus A, Iwanowicz-Palus GJ. Assessment of the relationship between socio-demographic \\ factors and intensity of perceived stress in a group of women hospitalized due to miscarriage. Med Og Nauk Zdr. 2021; 27(3): 285-290. \\ doi: $10.26444 /$ monz/140310
}

\section{Abstract}

Introduction. In the literature, there are reports that miscarriage causes deterioration of the mental condition of women. The presented study made it possible to identify socio-demographic risk factors of an increased level of stress. Objective. The aim of the study was to determine the correlation between socio-demographic factors and the intensity of perceived stress inae group of women who were hospitalized due to miscarriage.

Materials and method. 321 women aged 18-35 years hospitalized due to miscarriage took part in the study. The diagnostic survey method - the Perceived Stress Scale (PSS10) and the authors questionnaire were used.

Results. Age determined the intensity of stress, which was greater in the group of women aged up to 25 years than in the group of older women. Place of residence, education and financial situation did not determine the level of subjectively perceived stress in the group of women hospitalized due to miscarriage. Income determined the intensity of stress, which was the highest in the group of women with an income of up to 700 PLN per person in the family. The occurrence of miscarriages did not determine the level of subjectively perceived stress.

Conclusions. There is a correlation between sociodemographic factors and the intensity of perceived stress in the group of women who were hospitalized due to miscarriage. The assessment of the correlation between sociodemographic factors and the intensity of perceived stress made it possible to distinguish a group of women at increased risk of developing an increased level of stress, which includes women: up to 25 years of age and in the age range 31-35 years, with an income for one family member up to 700 PLN.

\section{Key words}

miscarriage, stress, socio-demographic factors

Address for correspondence: Grażyna Jolanta Iwanowicz-Palus, Chair and Department of Development in Midwifery, Faculty of Health Sciences, Medical University, Lublin, Poland

E-mail; spupalus@gmail.com

Received: 15.04.2021; accepted: 19.07.2021; on-line first: 22.07.2021

\section{Streszczenie}

Wprowadzenie. W literaturze przedmiotu znajdują się doniesienia o tym, że poronienie powoduje pogorszenie się kondycji psychicznej kobiet i zwiększenie ryzyka wystąpienia podwyższonego poziomu stresu. Przeprowadzone badania własne pozwoliły na zidentyfikowanie socjodemograficznych czynników ryzyka podwyższonego poziomu stresu.

Cel pracy. Celem pracy było określenie współzależności pomiędzy czynnikami socjodemograficznymi a natężeniem odczuwanego stresu w grupie kobiet hospitalizowanych z powodu poronienia.

Materiał i metody. Badaniami objęto 321 kobiet w wieku 18-35 lat hospitalizowanych z powodu poronienia. Badanie przeprowadzono metodą sondażu diagnostycznego z wykorzystaniem Skali Odczuwanego Stresu (PSS-10) i kwestionariusza ankiety autorskiej.

Wyniki. Wiek warunkował natężenie stresu, który był większy w grupie kobiet w wieku do 25 lat niż w grupie kobiet starszych. Miejsce zamieszkania, wykształcenie i sytuacja materialna nie miały wpływu na poziom subiektywnie odczuwanego stresu w grupie kobiet hospitalizowanych z powodu poronienia. Dochód implikował natężenie stresu, który był największy w grupie kobiet mających dochód do 700 zł na osobę w rodzinie. Występowanie poronień nie warunkowało poziomu subiektywnie odczuwanego stresu w grupie kobiet hospitalizowanych z powodu poronienia.

Wnioski. Istnieje współzależność pomiędzy czynnikami socjodemograficznymi a natężeniem odczuwanego stresu w grupie kobiet hospitalizowanych z powodu poronienia. Ocena współzależności pomiędzy czynnikami socjodemograficznymi a natężeniem odczuwanego stresu w grupie kobiet hospitalizowanych z powodu poronienia umożliwiła wyodrębnienie grupy kobiet dotkniętej zwiększonym ryzykiem wystąpienia podwyższonego poziomu stresu, która obejmuje kobiety: do 25. roku życia oraz w znajdujące się w przedziale wiekowym od 31 do 35 lat, o dochodzie na jednego członka rodziny do 700 zł.

\section{Słowa kluczowe}

poronienie, stres, czynniki socjodemograficzne 


\section{INTRODUCTION}

Psychological stress is classified as a civilization disease of the 21 st century [1]. In the related literature it is defined as a process which involves stressful experiences and physiological and psychological responses to a difficult situation [2]. Miscarriage causes deterioration of the mental condition of women and the negative impact of which is manifested by mood disorders and an increased risk of increased stress levels. Moreover, it is also proven that pregnancy loss is one of the most traumatic experiences in a woman $>$ life, during which the probability of stress symptoms increased $[2,3]$.

Miscarriage is one of the most common early reproductive complication $[2,4,5]$. Moreover, the number of miscarriages is a growing group not only in Poland, but also worldwide. Furthermore, the opinion that miscarriages are an epidemic of the 21 st century can be more often found in the literature. According to data of 2015, miscarriage occurs in $10 \%$ of all clinically recognized pregnancies, confirmed by medical history and laboratory tests [4]. Nowadays, the frequency of miscarriages is estimated at $15-20 \%$ of confirmed pregnancies and about $50 \%$ of all pregnancies $[6,7,8]$. According to the statistics, 23 million miscarriages are reported worldwide each year, which means that every minute 44 women lose their pregnancies. Moreover, it has been shown that the risk of miscarriage affects $15 \%$ of all diagnosed pregnancies. The incidence of this complication among women who have already had one miscarriage is $11 \%$, two miscarriages $-2 \%$, and more than three miscarriages $-0.7 \%$ [9].

According to the definition presented in 1972 by the World Health Organization (WHO), a miscarriage is the termination of pregnancy before the 22nd week of its duration, the consequence of which is the expulsion of an embryo or a foetus with a birth weight of less than $500 \mathrm{~g}$ from the uterine cavity $[10,11,12]$. In Poland, over 40,000 women lose their pregnancies every year for various reasons [11, 12]. About $80 \%$ of miscarriages occur before the 12 th week of pregnancy. Miscarriage and its somatic and non-somatic consequences concern $1-20 \%$ of young women $[11,13,14]$. It is assumed that the risk of miscarriage increases with the age of the woman $[15,16]$.

Women who experience miscarriage are exposed to very strong emotions. Surprise, fear, despair, anger, regret, depression and sadness alternate in a miscarriag, and might be described as a process in which the level of some experiences intensifies and others weaken. The intensity of experienced emotions and the ways of coping with them depend on many factors which shape the final picture of a miscarriage $[14,15,17]$.

A woman who experiences a miscarriage can manifest a stress load through: permanent or temporary withdrawal from interpersonal contacts, gradual or violent reactions to the situation. Disorders of mental functioning, depression and even suicidal tendencies may develop on the basis of long-lasting stress and lack of immediate professional help $[16,17,18]$. Long-term psychological effects of miscarriage may have a significant impact on women's health, may lead to anxiety and depression disorders, PTSD, and suicidal thoughts $[15,17,18]$.

Stress may deteriorate the functioning of a woman in various areas of life and lead to anxiety disorders and depression. It causes various, specific and non-specific changes in the human body, both in physiological and psychological sphere.
These changes affect behaviour, ability to work, and general health. Not all symptoms appear simultaneously, they may be associated with both acute and chronic stress $[18,19,20]$. The appearance of a stress reaction is related to the action of stressors, which are described as harmful external stimuli, e.g. socio-demographic factors [20, 21, 22]. Stress-inducing stimuli, stressors, are psychological and psychosocial, physical, biological and chemical factors that disturb the natural homeostasis of the body [22, 23, 24]. The factors causing stress may be divided according their intensity and strength, impact time and controllability. Traumatic stressors, regardless of individual human abilities, may affect basic human values such as life and health and may leave a mark on the psyche $[23,25,26]$.

Research in the area of the relationship between socio-demographic factors and the intensity of perceived stress in the group of women hospitalized due to miscarriage should be considered intentional. The obtained results may help to determine the characteristics of the group of women who require special care. Moreover, the results can be used in the development of preventive actions for anxiety disorders and depression which are consequences of untreated stress. The determination of factors influencing the increase of stress in the respondents may contribute to the optimization of treatment and development of coping mechanism for the extrasomatic consequences of miscarriage [25, 27].

\section{OBJECTIVE}

The aim of the study was to assess the relationship between socio-demographic factors and the intensity of perceived stress in a group of women who were hospitalized due to miscarriage.

\section{MATERIALS AND METHOD}

321 women hospitalized due to miscarriage, aged 18-35, with no psychiatric disorders took part in the study. The research was carried out from May 2014 - December 2015 in the gynaecology departments of three hospitals in Lublin, eastern Poland. The majority of respondents were aged 26-35 (78.8\%), married (78.2\%), residents of provincial cities $(52.0 \%)$, with higher education (66.4\%), white-collar workers (56.1\%), assessing their financial situation as good (57.3\%), and demonstrating no previous miscarriages (57.0\%).

The diagnostic survey method - the Perceived Stress Scale (PSS-10) and the author's questionnaire were used. Statistical analysis was performed with the use of IBM SPSS Statistics (version 22).

In order to determine the relationship between the studied variables, the correlation matrix and the Pearson correlation coefficient (quantitative variables with a normal distribution) and Spearman $`$ rank order (non-parametric variables) were used. Statistical significance (p) was determined at the level of $\mathrm{p}<0.05\left(^{\star}\right) ; 0.01\left(^{* *}\right)$ and $0.001\left(^{* * *}\right)$.

For quantitative variables, the arithmetic mean (M), median (Me), standard deviation (SD), skewness (A), skewness standard error (SEA), kurtosis (K), kurtosis standard error (SEk), minimum (min) and maximum (max.) were calculated. Normality plots and the Shapiro-Wilk Test were used to determine the distribution of each variable. The homogeneity 
Table 1. Socio-demographic characteristics of respondents

\begin{tabular}{|c|c|c|}
\hline Characteristics of the group & & $\begin{array}{c}\text { Respondents } \\
\text { n (\%) }\end{array}$ \\
\hline \multirow{4}{*}{ Age } & $18-20$ years of age & $10(3.1)$ \\
\hline & $21-25$ years of age & $58(18.1)$ \\
\hline & $26-30$ years of age & $122(38.0)$ \\
\hline & $31-35$ years of age & $131(40.80$ \\
\hline \multirow{4}{*}{ Marital status } & Single & $55(17.1)$ \\
\hline & Married & $251(78.2)$ \\
\hline & Widow & $2(0.6)$ \\
\hline & Divorced & $13(4.0)$ \\
\hline \multirow{4}{*}{ Place of residence } & Provincial city & $167(52.0)$ \\
\hline & District city & $49(15.3)$ \\
\hline & Other city & $13(4.0)$ \\
\hline & County & $92(28.7)$ \\
\hline \multirow{5}{*}{ Education } & Primary & $3(0.9)$ \\
\hline & Secondary & $67(20.9)$ \\
\hline & Post-secondary & $20(6.2)$ \\
\hline & Bachelor & $18(5.6)$ \\
\hline & Master & $213(66.4)$ \\
\hline \multirow{4}{*}{ Type of work } & Unemployed & 64 (19.9) \\
\hline & Intellectual job & $180(56.1)$ \\
\hline & Physical job & $65(20.2)$ \\
\hline & Student & $12(3.7)$ \\
\hline \multirow{4}{*}{$\begin{array}{l}\text { Subjective assessment of material } \\
\text { situation }\end{array}$} & Very good & $47(14.6)$ \\
\hline & Good & $184(57.3)$ \\
\hline & Average & $88(27.4)$ \\
\hline & Bad & $2(0.6)$ \\
\hline \multirow{6}{*}{ Number of miscarriages } & Absence & $183(57.0)$ \\
\hline & One & $94(29.3)$ \\
\hline & Two & $28(8.7)$ \\
\hline & Three & $10(3.1)$ \\
\hline & Four & $4(1.2)$ \\
\hline & Five & $2(0.6)$ \\
\hline
\end{tabular}

of variance in the studied groups was tested with the Levene's test. In order to determine the significance of the differentiation of the mean values of the variables in the compared groups, an analysis was performed by using the t-test for independent samples.

The study design received a positive opinion of the Bioethics Committee of the Medical University in Lublin (No. KE-0254/178/2014).

\section{RESULTS}

The mean point values on the scale of perceived stress in individual groups of women distinguished according to the place of residence were similar and amounted to 17.57 for the respondents living in provincial cities, 17.18 for the respondents living in a district city or another city, and 18.88 for women who indicated a village or a hamlet as their place of residence. Statistical analysis did not show any statistically significant differences $(p>0.05)$ between the mean values obtained in the compared groups.
The mean level of stress intensity among women with post-secondary and lower education was 18.40 and did not differ statistically significantly $(\mathrm{p}<0.05)$ from the average of 17.66 in the group of women with higher education. The mean values of the stress level, depending on the education, of women indicated the average intensity of stress in the studied group.

Statistical analysis demonstrated that education did not determine the level of subjectively perceived stress in the group of women who were hospitalized due to miscarriage.

The average level of stress intensity in women assessing their financial situation as very good / good was 17.56, and did not differ statistically significantly from the average of 18.67 in the group of women assessing their financial situation as medium or bad ( $p>0.05$ ). On the other hand, the mean in the scale of perceived stress for women with an income of up to 700 PLN was 20.06, and was significantly higher than the average of 17.19 for women with an income of 700 PLN-o 1,500 PLN, and significantly higher than the average of 17.83 for women ( $p<0.01)$ with an income over 1,500 PLN $(p<0.05)$. Comparative analysis did not show any other statistically significant differences $(p>0.05)$ between women with an income from 700 PLN - 1,500 PLN and women with an income above 1,500 PLN ( $p>0.05$ ).

The mean point values on the scale of perceived stress in the groups of women distinguished due to past miscarriages were similar, and reached respectively to 18.01 for those who have had miscarriages in the past and 17.77 for those who have not had any previous miscarriages. Statistical analysis showed no statistically significant differences $(p>0.05)$ between the mean values obtained in the compared groups.

\section{DISCUSSION}

Miscarriage is a traumatic experience for women and their families. Women who experience miscarriage face numerous medical and psychological consequences $[8,24,25$, 26]. The psychological consequences of miscarriage should be treated on a par with somatic and medical problems [4, $26,30]$. Studies on the quality of life demonstrated that $31 \%$ of women who had a miscarriage even one year after the event experienced a loss of sense of security and meaning in life. Mroczkowska (2011) in her study also showed that miscarriage resulted in a lower average women's quality of life compared to the average quality of life of women who had not experienced a miscarriage [30].

Our research on the relationship between socio-demographic variables and the level of subjectively perceived stress (PSS-10) showed that age statistically significantly determined the intensity of stress, which was higher in the group of women aged up to 25 years, compared to women aged $26-30$, and higher in the group of women aged $31-35$. Slusarska et al. (2014) showed a statistically significant relationship between the level of stress and age in a group of paramedics. Older paramedics showed a higher level of stress, compared to paramedics with a shorter employment history [1]. On the other hand, Murlikiewicz and Sieroszewski (2013) and Płoch et al. (2015) did not show any statistically significant relationships between age and the intensity of stress in the group of women who were hospitalized due to miscarriage $[8,31,32]$.

The analyzed data indicate that the place of residence, education and subjective assessment of the material situation 
Table 2. Mean values of scores on the perceived stress scale.

\begin{tabular}{|c|c|c|c|c|c|c|c|c|c|c|c|c|c|}
\hline \multicolumn{14}{|l|}{ In particular age groups } \\
\hline \multirow[b]{2}{*}{ Age } & \multirow[b]{2}{*}{$\mathrm{n}$} & \multirow[b]{2}{*}{ M } & \multirow[b]{2}{*}{ Me } & \multirow[b]{2}{*}{ SD } & \multirow[b]{2}{*}{ A } & \multirow[b]{2}{*}{$\mathrm{SE}_{\mathrm{A}}$} & \multirow[b]{2}{*}{ K } & \multirow[b]{2}{*}{$\mathrm{SE}_{\mathrm{K}}$} & \multirow[b]{2}{*}{ Min } & \multirow[b]{2}{*}{ Max } & \multicolumn{3}{|c|}{ Significance of differences } \\
\hline & & & & & & & & & & & & $\mathrm{t}$ & $\mathrm{p}$ \\
\hline 25 years of age and less $(\mathrm{I})$ & 68 & 20.22 & 20.00 & 6.22 & 0.22 & 0.29 & 0.67 & 0.57 & 5 & 38 & $I-I I$ & 3.469 & $0.001^{* *}$ \\
\hline $26-30$ years of age (II) & 122 & 16.91 & 16.00 & 6.35 & 0.01 & 0.22 & -0.50 & 0.43 & 2 & 31 & I-III & 2.788 & $0.006^{* *}$ \\
\hline $31-35$ years of age (III) & 131 & 17.54 & 18.00 & 6.53 & 0.14 & 0.21 & -0.41 & 0.42 & 3 & 35 & II-III & -0.779 & 0.437 \\
\hline \multirow{2}{*}{ Place of residence } & \multirow{2}{*}{$\mathrm{n}$} & \multirow{2}{*}{ M } & \multirow{2}{*}{ Me } & \multirow{2}{*}{ SD } & \multirow{2}{*}{ A } & \multirow{2}{*}{$\mathrm{SE}_{\mathrm{A}}$} & \multirow{2}{*}{ K } & \multirow{2}{*}{$\mathrm{SE}_{\mathrm{K}}$} & \multirow{2}{*}{ Min } & \multirow{2}{*}{ Max } & \multicolumn{3}{|c|}{ Significance of differences } \\
\hline & & & & & & & & & & & & $\mathrm{t}$ & $\mathrm{p}$ \\
\hline Provincial city (I) & 167 & 17.57 & 17.00 & 6.32 & 0.04 & 0.19 & -0.34 & 0.37 & 2.00 & 34 & $|-| \mid$ & 0.417 & 0.677 \\
\hline District city /other city (II) & 62 & 17.18 & 17.50 & 6.31 & -0.19 & 0.30 & -0.48 & 0.60 & 3.00 & 31 & I-III & 2.788 & 0.123 \\
\hline Country(III) & 92 & 18.88 & 19.00 & 6.89 & 0.26 & 0.25 & -0.12 & 0.50 & 3.00 & 38 & II-III & -1.555 & 0.116 \\
\hline \multirow{2}{*}{ Education } & \multirow[b]{2}{*}{$\mathrm{n}$} & \multirow{2}{*}{ M } & \multirow{2}{*}{ Me } & \multirow{2}{*}{ SD } & \multirow[b]{2}{*}{ A } & \multirow{2}{*}{$\mathrm{SE}_{\mathrm{A}}$} & & & & & & nce of di & ces \\
\hline & & & & & & & K & $\mathrm{SE}_{\mathrm{K}}$ & Min & Max & & & $\mathrm{p}$ \\
\hline Post-secondary or lower & 90 & 18.40 & 19.00 & 6.36 & 0.26 & 0.25 & 0.40 & 0.50 & 2 & 38 & & & 0362 \\
\hline Higher & 231 & 17.66 & 17.00 & 6.56 & 0.04 & 0.16 & -0.43 & 0.32 & 2 & 35 & & & \\
\hline
\end{tabular}

Table 3. Mean values of the scores on the perceived stress scale depending on the subjective assessment of the financial situation of the respondents and the income per person in the family.

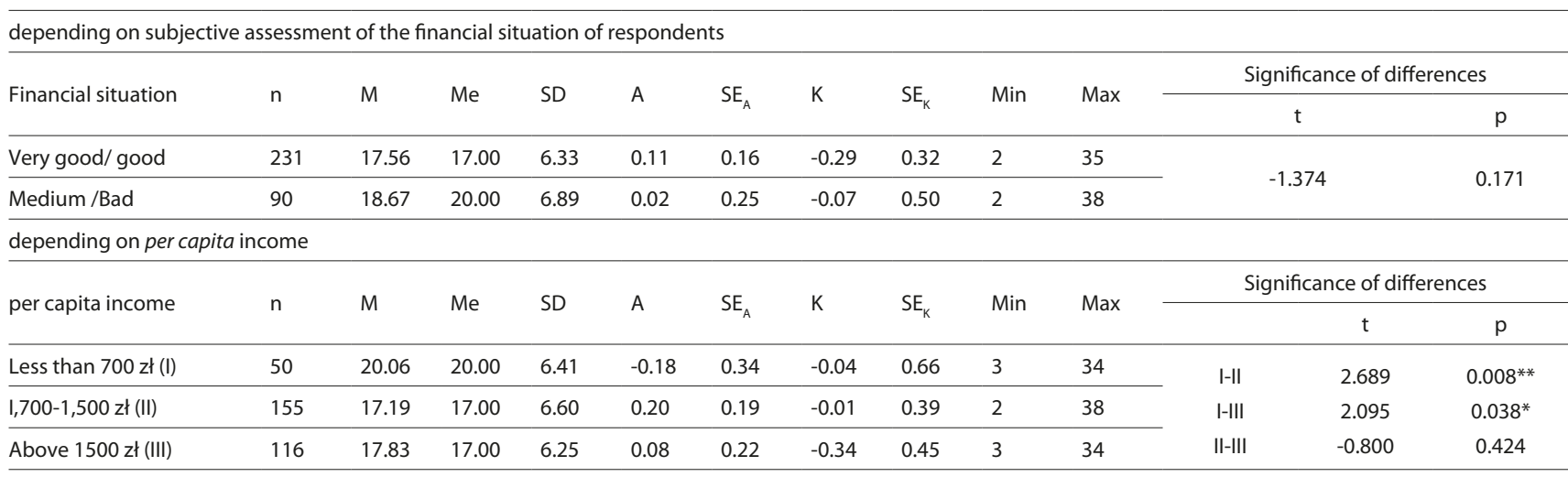

depending on the fact of previous miscarriages

\begin{tabular}{|c|c|c|c|c|c|c|c|c|c|c|c|c|}
\hline \multirow{2}{*}{ Miscarriage } & \multirow{2}{*}{$\mathrm{n}$} & \multirow{2}{*}{ M } & \multirow{2}{*}{$\mathrm{Me}$} & \multirow{2}{*}{ SD } & \multirow{2}{*}{ A } & \multirow{2}{*}{$\mathrm{SE}_{\mathrm{A}}$} & \multirow{2}{*}{$\mathrm{K}$} & \multirow{2}{*}{$\mathrm{SE}_{\mathrm{K}}$} & \multirow{2}{*}{ Min } & \multirow{2}{*}{ Max } & \multicolumn{2}{|c|}{ Significance of differences } \\
\hline & & & & & & & & & & & $\mathrm{t}$ & $\mathrm{p}$ \\
\hline Yes & 138 & 18.01 & 19.00 & 6.24 & -0.05 & 0.21 & -0.33 & 0.41 & 3 & 34 & \multirow{2}{*}{0.330} & \multirow{2}{*}{0.742} \\
\hline No & 169 & 17.77 & 17.00 & 6.71 & 0.19 & 0.18 & -0.14 & 0.36 & 2 & 38 & & \\
\hline
\end{tabular}

did not influence the level of subjectively perceived stress in the group of women who were hospitalized due to miscarriage. On the other hand, Engelhard et al. (2006) showed a statistically significant relationship between the occurrence of post-traumatic stress disorder (PTSD) and the education of the surveyed women. Post-traumatic stress disorder at a higher level was observed in the group of women with a low level of education. Thus, Engelhard et al. (2006) showed that education may play a protective role against the occurrence of an increased level of PTSD [31]. The cited study results also correspond with the results obtained by Daugrdajte et al. (2015), who showed that socio-demographic factors, such as the woman's age and lower level of education, determined the occurrence of stress symptoms, mainly (PTSD). Based on reports from the literature, it can be concluded that education may play the role of a buffer against the symptoms of stress occurring in the group of women who were hospitalized due to miscarriage $[33,34]$.

In the group of respondents, income determined the intensity of stress, which was the highest in the group of women with an income of up to 700 PLN in the family. No studies on the correlation between income per one family member and the level of stress intensity in the group of women hospitalized due to miscarriage were found in the literature. It is commonly known that stress is associated with the occurrence of a miscarriage. Low socio-economic status can contribute to the development of chronic stress. Therefore, there is a reasonable supposition that in the group of women with relatively low income per capita in the family, high levels of stress could have occurred earlier (i.e. before pregnancy) and could have influenced the course of shaping the woman's psychosocial figure [35]. 
The study shows that the occurrence of miscarriages in the past did not determine the level of subjectively perceived stress in the respondents group. Miscarriage is accompanied by stress, which may increase due to the necessity of hospitalization and implementation of treatment $[11,15]$. The literature also includes the results of studies by Blackmore et al. (2011), which showed that the experience of miscarriage increased the level of stress and negative emotions. On the other hand, McCarthy and Tong (2015), and Nakano et al. (2013), showed that having one or more miscarriages increased the level of stress and even depressive symptoms [34, 35]. Moreover, Kong et al. (2013) observed that the highest level of stress was observed in the studied group of women in the first days after the miscarriage, and showed a downward trend with time [37].

Treppesch et al. (2015) conducted a study in a group of 921 women and showed that obstetric complications, including miscarriages, increased the level of stress, which remained high for several years [36, 38, 39]. Moreover, Bowles et al. (2006) reported that miscarriage was a risk factor for increased levels of stress. The authors claimed that unrecognized and untreated stress following a traumatic event led to the development of PTSD symptoms. According to these studies, $28 \%$ of the respondents showed symptoms of acute stress and $39 \%$ of women showed symptoms of PTSD one month after miscarriage. Additionally, Bowles et al. (2006) demonstrated that factors such as illnesses during pregnancy also contributed to increased stress levels. In turn, studies by Cheung et al. (2013) showed that women who used assisted reproductive technology and experienced a first-trimester miscarriage, experienced significantly higher levels of stress compared to women who conceived naturally. This issue was not the subject of the current study, while the results obtained by other researchers in this area may significantly contribute to the improvement of the diagnosis of women treated for miscarriage, especially exposed to long-term consequences of stress [37, 39, 40, 41].

Care for a woman who experiences a miscarriage should have a holistic character. All support components are important, i.e. psychological, spiritual / religious help, and professional medical care $[7,42,43,44,45]$. The attitude of the medical staff and the quality of the care provided directly affect the woman and her family, and may also affect the course of subsequent stages of mourning and significantly affect the number of symptoms of grief, depression and post-traumatic stress disorder $[44,45,46,47]$.

In conclusion, the study has shown that age and income may contribute to the increased level of perceived stress in the group of women who were hospitalized due to miscarriage. There is a correlation between socio-demographic factors and the intensity of perceived stress in the group of women hospitalized due to miscarriage. Therefore, the results of this study indicate that special care is required in the group of respondents aged up to 25 , and women in the age range 31-35, with an income below 700 PLN per family member. Providing individual psychological support in this group of women may reduce the risk of developing long-term psychological consequences of miscarriage $[50,52,54]$.

\section{CONCLUSIONS}

1. There is a relationship between socio-demographic factors and the intensity of perceived stress in the group of women who were hospitalized due to miscarriage.

2. Assessment of the relationship between socio-demographic factors and intensity of the perceived stress in the group of women who were hospitalized due to miscarriage made it possible to distinguish a group of respondents at increased risk of developing an increased level of stress. The group included women aged up to 25 and in the age range from 31-35, with an income of up to 700 PLN per family member.

\section{REFERENCES}

1.Ślusarska B, Nowicki G, Jędrzejewicz D. Poziom odczuwanego stresu i czynniki stresogenne na stanowisku pracy ratownika medycznego. Pielęgniarstwo XXI wieku 2014; 1(46): 11-18.

2. Olesen ML, Graungaard AH, Husted GR. Deciding treatment for miscarriage-experiences of women and healthcare professionals. Scan J Caring Sci. 2015; 29(2): 386-394.

3. Pietropolli A, Bruno V, Ticconi C. Uterine blood flow indices, antinuclear autoantibodies and unexplained recurrent miscarriage. Obst Gynecol Sci. 2015; 58(6): 453-460.

4. Nynas J, Narang P, Kolikonda MK, Lippmann S. Depression and Anxiety Following Early Pregnancy Loss: Recommendations for Primary Care Providers. Prim Care Companion CNS Disorders 2015; 17(1): 1-6.

5. Ojule JD, Ogu RN. Miscarriage and Maternal Health. In Complications of Pregnancy. Intech Open 2019: 14-16.

6. San Lazaro Campillo I, Meaney S, McNamara K, O'Donoghue K. Psychological and support interventions to reduce levels of stress, anxiety or depression on women >s subsequent pregnancy with a history of miscarriage: an empty systematic review. Br Med J Open 2017; 7(9): 6-9.

7. Volgsten H, Jansson C, Svanberg AS, Darj E, Stavreus-Evers A. Longitudinal study of emotional experiences, grief and depressive symptoms in women and men after miscarriage. Midwifery 2018; 64: 23-28.

8. Miller SC. The Moral Meanings of Miscarriage. J Soc Philosophy 2015; 46(1): 141-157.

9. Quenby S, Gallos ID, Dhillon-Smith RK, Podesek M, Stephenson MD, Fisher J, et al. Miscarriage matters: the epidemiological, physical, psychological, and economic costs of early pregnancy loss. The Lancet 2021; 397: 1658-1667.

10. Napiórkowska-Orkisz M, Olszewska J. Rola personelu medycznego we wsparciu psychicznym kobiety i jej rodziny po przebytym poronieniu. Pielęgniarstwo Pol. 2017; 3(65): 529-536.

11. Djidonou A, Tchegnonsi FT, Ahouandjinou CC, Ebo BH, Bokossa CM, Degla J, Fiossi-Kpadonou É. Prevalence and Factors Associated with Anxiety and Depression in Expectant Mothers at Parakou in 2018. Open J Psychiatry 2019; 9: 235-247.

12. Chrzan-Dętkoś M, Walczak-Kozłowska T. Antenatal and postnatal depression - Are Polish midwives really ready for them? Midwifery 2020; 8: 9-11.

13. Huffman CS, Schwartz AT, Swanson KM. Couples and Miscarriage: The Influence of Gender and Reproductive Factors on the Impact of Miscarriage. Women's Health Issues 2015; 25(5): 570-578.

14. Dembińska A, Wichary E. Wybrane psychospołeczne korelaty lęku przedporodowego - znaczenie dla praktyki położniczej. Selected psycho-social correlates of antenatal anxiety - and their signify cancer for obstetrics care. Sztuka Leczenia 2016; 43(1): 43-54.

15. Sikora K. Reakcje kobiet po stracie ciąży oraz zachowania ich partnerów. Ginekol Położnictwo 2014; 9(3): 40-55.

16. Ilska M, Przybyła-Basista H. Measurement of women's prenatal attitudes towards maternity and pregnancy and analysis of their predictors. Health Psychol Rep. 2014; 2(3): 176-188.

17.ESHRE-European Society of Human Reproduction and Embryology: Special Interest Group for Early Pregnancy RCOG-Green Top Guideline 2006: 25.

18. Chrzan-Dętkoś M, Kalita L. Rola wczesnej interwencji psychologicznej w profilaktyce i terapii depresji poporodowej. Psychoterapia 2019; 1(188): 47-61. 
19. Amirchaghmaghi E, Rezaei A, Aflatoonian R. Gene Expression Analysis of VEGF and Its Receptors and Assessment of Its Serum Level in Unexplained Recurrent Spontaneous Abortion. Cell J Winter 2015; 16(4): 583-545.

20. Sariibrahim Astepe B, Bosgelmez S. Antenatal Depression and anxiety among women with Threatened Abortion: a CaseControl Study. Gynecol Obst Reproductive Med. 2019; 25: 17.

21. Mutiso, SK, Murage, A, Mwaniki, AM. Factors associated with a positive depression screen after a miscarriage. BMC Psychiatry 2019; 19: 8 .

22. Duval R, Javanbakht A, Liberzon I. Neural circuits in anxiety and stress disorders: a focused review. Ther Clin Risk Management 2015; 11: 115-126.

23. Betts KS, Williams GM, Najman JM, Alati R. Maternal depressive, anxious, and stress symptoms during pregnancy predict internalizing problems in adolescence. Depress Anxiety. 2014; 31(1): 9-18.

24. Likis EF, Sathe NA, Carnahan R, Mc Pheeters MA. Systematic review of validated. methods to capture stillbirth and spontaneous abortion using administrative or claims data. Vaccine 2013; 31: 74-82.

25. Robinson E. Pregnancy loss. Best Practice Res Clin Obst Gynecol. 2014; 28: 169-178.

26. Cannella BL, Yarcheski, A, Mahon, NE. Meta-Analyses of Predictors of Health Practices in Pregnant Women. West J Nurs Res. 2018; 40(3): 425-446.

27. Rymaszewska J, Szcześniak D, Cubała WJ, Gałecki P, Rybakowski J, Samochowiec J, Szulc A, Dudek D. Rekomendacje Polskiego Towarzystwa Psychiatrycznego dotyczące leczenia zaburzeń afektywnych u kobiet w wieku rozrodczym. Część III: Postępowanie w wypadku utraty ciąży oraz niepowodzeń w leczeniu niepłodności metodą in vitro. Psychiatria Pol. 2019; 53(2): 277-292.

28. Borhart J, Bavolek R. Obstetric and Gynecologic Emergencies, An Issue of Emergency Medicine Clinics of North America. Elsevier Health Sci; 2019.

29. Dunkel SC, Tanner L. Anxiety, depression and stress in pregnancy: implications for mothers, children, research, and practice. Curr Opin Psychiatry 2012; 25(2): 141-148.

30. Mroczkowska D. Jakość życia kobiet po poronieniu ciąży. Życie i Płodność 2011; 4: 77-88.

31.Płoch K, Dziedzic M, Matuszyk D, Frączek E. Czynniki sprzyjające utrzymaniu ciąży wśród kobiet hospitalizowanych z powodu zagrażającego poronienia. Pielęgniarstwo XXI wieku 2015; 4(53): 69-74.

32. Murlikiewicz M, Sieroszewski P. Poziom depresji, lęku i objawów zaburzenia po stresie pourazowym w następstwie poronienia samoistnego. Perinatologia, Neonatologia i Ginekologia 2013; 6(2): 93-98.

33. Engelhard IM, Hout MA, Schouten EG. Neuroticism and low educational level predict the risk of posttraumatic stress disorder in woman after miscarriage or stillbirth. Gen Hospital Psychiatry 2006; 28: 417-424.

34. Daugirdaité V, van den Akker O, Purewal S. Posttraumatic Stress and Posttraumatic Stress Disorder after Termination of Pregnancy and Reproductive Loss: A Systematic Review. J Pregnancy. 2015: 1-14.

35.https://cordis.europa.eu/article/id/125241-the-latest-culprit-of-poor-health-and-early-death-low-socioeconomic-status/pl
36. Blackmore ER, Côté-Arsenault D, Tang W, Glover V, Evans J, Golding J, O'Connor TG. Previous prenatal loss as a predictor of perinatal depression and anxiety. Br J Psychiatry. 2011; 198(5): 373-378.

37. McCarthy EA, Tong S. Diagnosing a miscarriage. Br Med J. 2015; 351: $1-2$.

38. Nakano Y, Akechi T, Furukawa TA, Sugiura-Ogasawara M. Cognitive behavior therapy for psychological distress in patients with recurrent miscarriage. Psychol Res Behav Management 2013; 6: 37-43.

39. Kong GWS, Lok IH, Yiu AK, Hui ASY, Lai BPY, Cheung TKH. Clinical and psychological impact after surgical, medical or expectant management of first-trimester miscarriage - a randomized controlled trial. Aust N Z J Obstet Gynecol, 2013; 53(2): 170-177.

40. Treppesch KI, Beyer R, Geissner E, Rauchfuß M. Backdating miscarriages and abortions in patients at practice-based gynecological offices: Worth a question? Woman Psychosom Gynecol Obstet. 2015; 1-2: 9-15.

41. Bowles SV, Bernard RS, Epperly T, Woodward S, Ginzburg K, Folen R, Perez T, Koopman C. Traumatic stress disorders following first-trimester spontaneous abortion. J Family Pract. 2006; 55(11): 969-973.

42. Cheung C, Chan C, Ng E. Stress and anxiety depression levels following first-trimester miscarriage: a comparison between women who conceived naturally and woman who conceived with assisted reproduction. Int J Obstet Gynecol. 2013; 120: 1090-1097.

43. Bubiak A, Bartnicki J, Knihnicka-Mercik Z. Psychologiczne aspekty utraty dziecka w okresie prenatalnym. Zdr Publ. 2014; 4(1): 69-78.

44. Sikora K. Reakcje kobiet po stracie ciąży oraz zachowania ich partnerów. Ginekologia i Położnictwo 2014; 9(3): 40-55.

45. Toffol E, Koponen P, Partonen T. Miscarriage and mental health: Results of two population-based studies. Psychiatry Res. 2013; 205: 151-158.

46. Kersting A, Wagner B. Complicated grief after perinatal loss. Dialogues Clin Neurosci. 2012; 14(7): 187-194.

47. Holka-Pokorska J, Jarema M, Wichniak A. Kliniczne uwarunkowania zaburzeń psychicznych występujących w przebiegu terapii niepłodności. Psychiatria Pol. 2015; 49(5): 965-982.

48. Dugiel G, Tustanowska B, Kęcka K, Jasińska M. Przegląd teorii stresu, Acta Scientifica Academiae Ostroviensis, Sectio B, Nauki Medyczne, Kultura Fizyczna i Zdrowie 2012; 47-70.

49. Blackmore ER, Côté-Arsenault D, Tang W, Glover V, Evans J, Golding J, O'Connor TG. Previous prenatal loss as a predictor of perinatal depression and anxiety. Br J Psychiatry. 2011; 198(5): 373-378.

50. Sygit-Kowalkowska E. Radzenie sobie ze stresem jako zachowanie zdrowotne człowieka perspektywa psychologiczna. Hygea Public Health 2014; 49(2): 202-208.

51. Borhart J, Bavolek R. Obstetric and Gynecologic Emergencies, An Issue of Emergency Medicine Clinics of North America. Elsevier Health Sci. 2019.

52. Adib-Rad H, Basirat Z, Faramarzi M, Mostafazadeh A, Bijani A. Psychological distress in women with recurrent spontaneous abortion: a case-control study. Turk J Obstet Gynecol. 2019; 16(3): 151-157.

53. Guzewicz M. Psychologiczne i społeczne konsekwencje utraty dziecka po poronieniu. Civitas et Lex 2014; 1: 15-27.

54. Ockhuijsen HDL, Hoogen A, Boivin J, Macklon NS, Boer F. Pregnancy After Miscarriage: Balancing Between Loss of Control and Searching for Control. Resn Nurs Health. 2014; 37: 267-275. 